\title{
Meningkatkan Hasil Belajar Sub Tema Tubuhku Melalui Pendekatan Tematik Dengan Menggunakan Teknik Reward Pada Siswa Kelas I Semester I SDN Sintung Timur Tahun Pelajaran 2018/2019
}

\author{
Nurulaini \\ Guru Kelas SDN Sintung Timur Kec. Pringgarata Kab. Lombok Tengah
}

\begin{abstract}
Abstrak. Jenis penelitian ini adalah penelitian tindakan kelas dengan subjek penelitian siswa kelas I semester 1 SDN Sintung Timur Kecamatan Pringgarata Kabupaten lombok Tengah. Penelitian ini dilaksanakan pada semester I bulan Agustus sampai dengan bulan Oktober 2018, dengan jumlah sampel sebanyak 25 siswa terdiri dari 15 siswa laki - laki dan 10 siswa perempuan dan model penelitian yang digunakan model Kemmis dan Mc Tanggar. Berdasarkan hasil penelitian tindakan kelas tentang hasil belajar siswa menunjukkan peningkatan. Pada kondisi awal, ketuntasan belajar siswa mencapai 36\%. Pada siklus satu menjadi $60 \%$ dan siklus kedua mencapai angka $92 \%$. Peningkatan tersebut terjadi pada seluruh indikator yang yang ingin dicapai . Dikatakan peningkatan cukup signifikan hasil belajar siswa dari sikus I ke siklus II dimana pada siklus I diperoleh nilai rata - rata sebesar 65 meningkat pada siklus II menjadi 84,46 terjadi peningkatan sebesar 19,46 poin ,kemudian persentase ketuntasan dari siklus I sebesar $60 \%$ meningkat pada siklus II menjadi $92 \%$ meningkat sebesar 32 poin ,maka dengan demikian dapat ditarik kesimpulan bahwa pendekatan tematik dengan media biodrawing dapat meningkatkan aktivitas siswa dalam pembelajaran bahasa Indonesia, matematika, dan SBDP pada siswa kelas I SD Negeri Sintung Timur Kecamatan Pringgarata. Kabupaten Lombok Tengah Tahun Pelajaran 2018/2019. dengan demikian Media Biodrawing dapat dijadikan sebagai salah satu alternatif media pembelajaran yang disesuaikan dengan materi Pelajran.
\end{abstract}

\section{Kata Kunci: Aktivitas Belajar, Pendekatan Tematik, Media Biodrawing}

\section{PENDAHULUAN}

\section{Latar Belakang}

Pendidikan tidak dapat dipisahkan dari manusia. Menurut H. A. R Tilaar (2002: 29), keberadaan pendidikan tidak terlepas dari keberadaan manusia. Pendidikan terjadi sejak manusia lahir, bahkan sejak berada dalam kandungan sudah terjadi pendidikan hingga akhir hayat. Melalui pendidikan, manusia diharapkan dapat meningkatkan dan mengembangkan seluruh potensi atau bakat alamiahnya sehingga nantinya menjadi manusia yang dapat berdaya guna dan berhasil guna (Achmad Dardiri dalam Dwi Siswoyo, 2007: 1). Hal tersebut senada dengan pengertian pendidikan dalam Undang-Undang RI Nomor 20 Tahun 2003 tentang Sistem Pendidikan Nasional pasal 1 yang menyebutkan bahwa, "Pendidikan adalah usaha sadar dan terencana untuk mewujudkan suasana belajar dan proses pembelajaran agar peserta didik secara aktif mengembangkan potensi dirinya untuk memiliki kekuatan spiritual keagamaan, pengendalian diri, kepribadian, kecerdasan, akhlak mulia, serta keterampilan yang dibutuhkan bagi dirinya, masyarakat dan bangsa."

Pembelajaran harus mengarah pada upaya meningkatkan potensi siswa secara komprehensif serta upaya meningkatkan kegiatan guru dalam mengajar, maka pembelajaran harus dikembangkan sesuai dengan prinsip-prinsip yang benar. Prinsipprinsip belajar menurut Dimyati dan Mujiono (2013: 42) berkaitan dengan (1) perhatian dan motivasi, (2) keaktifan, (3) keterlibatan langsung, (4) pengulangan, (5) tantangan, (6) balikan dan penguatan, serta (7) perbedaan individual. Selain prinsip-prinsip belajar, terdapat faktor-faktor yang berpengaruh dalam kegiatan belajar dan pembelajaran yang harus diperhatikan. Lingkungan sekolah mencakup metode mengajar, kurikulum, relasi guru dengan siswa, relasi antar siswa, disiplin sekolah, pengajaran dan 
waktu sekolah, standar pelajaran, keadaan gedung, metode mengajar, dan tugas rumah.

Pembelajaran di SD pada kurikulum 2013 baik kelas rendah maupun kelas tinggi menggunakan pembelajaran tematik integratif. Pembelajaran tematik integratif adalah pendekatan pembelajaran yang mengintegrasikan berbagai kompetensi dari berbagai matapelajar an ke dalam berbagai macam tema (Permendikbud, 2013). Adapun ciri-ciri dalam pembelajaran tematik integratif (Trianto, 2011: 163-164) antara lain: (1) berpusat pada anak, (2) memberikan pengalaman langsung, (3) pemisahan antar mata pelajaran tidak nampak, (4) menyajikan konsep dari beberapa mata pelajaran dalam satu PBM, (5) bersifat luwes, dan (6) hasil pembelajaran dapat berkembang sesuai dengan minat dan kebutuhan anak. Dalam kegiatan belajar dan pembelajaran hendaknya diperhatikan faktor-faktor yang mempengaruhi kegiatan belajar serta ciri-ciri dari pembelajaran yang digunakan. Apabila hal-hal tersebut tidak diperhatikan, maka yang timbul adalah permasalahan belajar. Seperti yang dialami SDN Sintung Timur Kecamatan Pringgarata Kab. Lombok Tengah. Adapun masalah yang ditemukan di SDN Sintung Timur Kecamatan Pringgarata Kab. Lombok Tengah adalah rendahnya hasil belajar siswa dimana dari hasil pengolahan nilai ulangan harian dari 25 jumlah peserta didik yang berhasil mencapai KKM sebanyak 9 siswa atau ketuntasan belajar sebesar $36 \%$ sedangkan 16 siswa atau $64 \%$ belum mencapai KKM. Dimana KKM yang ditetapkan SDN Sintung Timur yaitu 70 untuk tahun pelajaran 2018/2019.

Rendahnya hasil belajar dipengaruhi oleh beberapa faktor diantanya metode pembelajaran yang digunakan masih monoton, media pembelajaran yang tidak menarik.

Berdasarkan permasalahan tersebut diatas maka peneliti menawarkan solusinya dengan menggunakan metode biodrawing dalam pembelajaran tematik,sehingga peneliti mengangkat judul penelitian "Meningkatkan Hasil Belajar Sub Tema Tubuhku melalui Pendekatan Tematik dengan Menggunakan
Teknik Reward pada Siswa Kelas I Semester I SDN Sintung Timur Tahun Pelajaran 2018/2019

\section{Rumusan masalah}

Berdasarkan latar belakang tersebut diatas, rumusan masalah dalam penelitian ini adalah, bagaimanakah Meningkatkan Hasil Belajar Sub Tema Tubuhku melalui Pendekatan Tematik dengan Menggunakan Teknik Reward pada Siswa Kelas I Semester I SDN Sintung Timur Tahun Pelajaran 2018/2019?.

\section{Tujuan penelitian}

Sesuai dengan rumusan masalah yang telah diuraikan, maka tujuan penelitian ini adalah untuk Meningkatkan Hasil Belajar Sub Tema Tubuhku melalui Pendekatan Tematik dengan Menggunakan Teknik Reward pada Siswa Kelas I Semester I SDN Sintung Timur Tahun Pelajaran 2018/2019.

\section{Manfaat penelitian}

Penelitian ini diharapkan dapat memberikan manfaat sebagai berikut:

1. Secara Teoritis

Penelitian ini memberikan sumbangan pemikiran untuk mengetahui manfaat pemilihan teknik reward guna meningkatkan hasil belajar siswa.

2. Secara Praktis

a. Bagi siswa

Membantu siswa membangkitkan motivasi internal dalam pembelajaran tematik integratif melalui motivasi eksternal yang diberikan guru berupa teknik reward dengan ditandai meningkatnya hasil belajar siswa.

b. Bagi guru

Memberikan pengetahuan mengenai teknik reward yang dapat digunakan guru sebagai motivator dalam pembelajaran tematik integratif untuk meningkatkan hasil belajar siswa.

c. Bagi sekolah

Bahan pertimbangan bagi sekolah dalam mengambil kebijakan yang terkait dengan teknik pembelajar an yang digunakan oleh guru untuk memotivasi siswa dalam 
pembelajaran tematik integr atif sehingga dapat memperbaiki kualitas proses pembelajaran.

\section{LANDASAN TEORI DAN KAJIAN PUSTAKA \\ Hasil Belajar}

Kata Hasil banyak digunakan dalam dunia pendidikan, khususnya dalam pembelajaran. Kata Hasil dapat diartikan sebagai hasil usaha. Sunarto (2009) mendefinisikan Hasil sebagai kecakapan atau hasil konkret yang dapat dicapai pada saat atau periode tertentu.

Menurut Saifudin Azwar (2011: 13) Hasil adalah hasil yang dicapai siswa dalam belajar. Sedangkan menurut Asep Jihad dan Abdul Haris (2009:64) Hasil belajar adalah ketercapaian setiap kemampuan dasar, baik kognitif, afektif, maupun psikomotor, yang diperoleh siswa selama mengikuti pembelajaran tertentu. Sunarto (2009) mengemukakan bahwa Hasil belajar adalah hasil pengukuran dari penilaian usaha belajar yang dinyatakan dalam bentuk simbol, huruf, maupun kalimat yang mencerminkan hasil yang sudah dicapai oleh setiap peserta didik dalam periode tertentu, yang meliputi faktor kognitif, afektif, dan psikomotor setelah mengikuti proses pembelajaran yang diukur dengan menggunakan instrument tes yang relevan.

Pendapat lain tentang Hasil belajar dikemukakan oleh Winkel (2004:57), yang mendefinisikan Hasil belajar sebagai pencapaian kemampuan kognitif yang meliputi pengetahuan dan kemampuan setelah proses pembelajaran. Hasil belajar adalah hasil pengukuran dari penilaian usaha belajar yang dinyatakan dalam bentuk simbol, atau huruf maupun kalimat yang menceritakan hasil yang sudah dicapai oleh setiap siswa pada periode tertentu. Hasil belajar merupakan hasil dari pengukuran terhadap siswa yang meliputi faktor kognitif setelah mengikuti proses pembelajaran yang diukur dengan menggunakan instrumen tes yang relevan. Senada dengan pendapat Winkel, Zaenal Arifin (2009:12), juga mengemukakan bahwa Hasil belajar pada umumnya hanya berkenaan dengan aspek pengetahuan (kognitif), sedangkan aspek-aspek pembentukan watak (afektif dan psikomotor) merupakan hasil belajar.

$$
\text { Saifudin Azwar (2011 : 8-9) }
$$

mengemukakan bahwa tes Hasil belajar bertujuan untuk mengungkap keberhasilan seseorang dalam belajar. Tujuan ini membawa keharusan dalam konstruksinya untuk selalu mengacu pada perencanaan program belajar yang dituangkan dalam silabus masingmasing mata pelajaran. Tes Hasil belajar berupa tes yang disusun secara terencana untuk mengungkap performasi maksimal subyek dalam menguasai bahan- bahan atau materi yang telah diajarkan. Dalam kegiatan pendidikan formal tes Hasil belajar dapat berbentuk ulangan harian, tes formatif, tes sumatif, bahkan ujian nasional dan ujian masuk perguruan tinggi.

Berdasarkan beberapa pendapat mengenai pengertian Hasil belajar yang telah diuraikan di atas, dapat disimpulkan bahwa Hasil belajar adalah hasil pengukuran terhadap kemampuan kognitif peserta didik setelah mengikuti proses pembelajaran menggunakan instrumen tes yang relevan dan dinyatakan dalam bentuk nilai tes atau angka. Dalam penelitian ini Hasil belajar yang diukur adalah Hasil belajar IPA.

Peneliti sependapat dengan penekanan Hasil belajar pada aspek kognitif seperti pendapat winkle dan Zaenal Arifin. Dalam penelitian ini juga akan menggunakan istilah Hasil belajar hanya mengacu pada nilai hasil kognitif saja.

\section{Faktor-faktor yang Mempengaruhi Hasil Belajar}

Ngalim Purwanto (2007:102-105) mengemukakan bahwa tinggi rendahnya Hasil belajar siswa dipengaruhi oleh 2 faktor yaitu :

a. Faktor individual, adalah faktor yang ada pada diri organisme itu sendiri. Ada pun yang dapat digolongkan ke dalam faktor intern, yaitu kematangan/ pertumbuhan, kecerdasan, latihan, motivasi,dan sifat pribadi seseorang.

b. Faktor sosial, adalah faktor-faktor yang dapat mempengaruhi Hasil belajar yang sifatnya di luar diri siswa, meliputi factor keluarga/keadaan rumah tangga, guru dan cara mengajarnya, alat-alat yang digunakan dalam belajar mengajar, 
lingkungan, kesempatan yang tersedia, dan motivasi sosial.

Senada dengan pendapat di atas, Slameto (2003: 54) mengemukakan bahwa Hasil belajar siswa dipengaruhi oleh faktor yang ada dalam individu yang sedang belajar (faktor intern), dan faktor yang ada di luar individu (faktor ekstern).

\section{Pembelajaran Tematik Integratif}

Dalam Peraturan Menteri

Pendidikan dan Kebudayaan Republik Indonesia tentang No. 67 tahun 2013 tentang Kerangka Dasar dan Struktur Kurikulum SD/ MI bahwa pelaksanaan kurikulum 2013 pada SD/ MI dilakukan melalui pembelajaran dengan pendekatan pembelajaran tematik integratif dari kelas I sampai kelas VI. Pembelajaran tematik integratif adalah pendekatan pembelajaran yang mengintegrasikan berbagai kompetensi dari berbagai matapelajaran ke dalam berbagai tema.

Pendekatan yang digunakan untuk mengintegrasikan kompetensi dasar dari berbagai matapelajaran yaitu intradisipliner, inter-disipliner, multi-disipliner, dan trans-disipliner (Permendikbud, 2013). Integrasi intra-disipliner dilakukan dengan cara mengintegrasikan dimensi sikap, pengetahuan, dan keterampilan menjadi satu kesatuan yang utuh di setiap matapelajaran. Integrasi inter- disipliner dilakukan dengan menggabungkan kompetensi-kompetensi dasar beberapa mata pelajaran agar terkait satu dengan yang lainnya, sehingga dapat saling memperkuat, menghindari terjadinya tumpang tindih, dan menjaga keselarasan pembelajaran. Integrasi multi-disipliner dilakukan tanpa menggabungkan kompetensi dasar tiap matapelajaran sehingga tiap matapelajaran masih memiliki kompetensi dasarnya sendiri. Integrasi trans- disipliner dilakukan dengan mengaitkan berbagai mata pelajaran yang ada dengan permasalahan-permasalahan yang dijumpai di sekitarnya sehingga pembelajaran menjadi kontekstual.

$$
\text { Adapun karakteristik dari }
$$
pembelajaran tematik integratif (Trianto, 2011: 163-164) antara lain:

a. Berpusat pada siswa
Pada pembelajaran tematik integratif berpusat pada siswa (student centered), sedangkan guru bertugas sebagai fasilitator yang membantu siswa memudahkan dalam kegiatan belajar.

b. Memberi pengalaman langsung

Pembelajaran tematik memberikan pengalaman langsung pada siswa ( direct experiences ). Unruk memberikan pengalaman langsung, siswa dihadapkan pada sesuatu yang nyata (konkret) sebagai dasar untuk memahami konsep yang abstrak.

c. Pemisahan matapelajaran tidak begitu jelas.

Dalam pembelajarn tematik integratif, pemisahan antar matapelajaran tidak begitu kentara, namunpembelajaran difokuskan pada tema-tema yang berkaitan dengan kehidupan siswa.

d. Menyajikan konsep dari berbagai matapelajaran.

Konsep-konsep yang terdapat dari beberapa matapelajaran yang digabungkan dalam satu tema disajikan dalam satu pembelajaran.

e. Bersifat fleksibel.

Pembelajaran tematik integratif bersifat luwes (fleksibel) di mana guru dapat mengaitkan bahan ajar dari satu matapelajaran dengan matapelajaran lainnya, dengan mengaitkan kehidupan siswa dan keadaan lingkungan sekolah, keluarga, dan masyarakat.

f. Menggunakan prinsip belajar sambil bermain dan menyenangkan.

Pembelajaran tematik integratif ini mengadopsi prinsip belajar PAKEM yakni pembelajaran aktif, kreatif, efektif dan menyenangkan. Selain karakteristik di atas, terdapat karakteristik lain menurut Kemendikbud (dalam Trianto, 2011: 165166), yaitu:

a. Holistik

Pembelajaran memungkinkan siswa untuk memahami fenomena dari segala sisi. Sehingga ketika siswa dihadapkan pada suatu masalah, siswa dapat lebih bijak dalam menyikapinya. 
b. Bermakna

Hubungan antara konsep-konsep yang disajikan dalam suatu pembelajaran akan berdampak pada kebermaknaan dari materi yang dipelajari siswa.

c. Autentik

Pembelajaran tematik integratif memungkinkan siswa memahami secara langsung prinsip dan konsep yang ingin dipelajarinya melalui kegiatan langsung, dan guru sebagai fasilitator.

d. Aktif

Pembelajaran tematik integratif menekankan keaktifan siswa dalam pembelajaran baik secara fisik, mental, intelektual, maupun emosional untuk mencapai hasil belajar yang optimal dengan mempertimbangkan hasrat, minat, dan kemampuan siswasehingga memotivasi siswa untuk terus menerus belajar.

\section{Teknik Reward}

Dalam pembelajaran, diperlukan teknik-teknik pembelajaran yang sesuai dengan metode pembelajaran. Hal ini disebabkan metode dan teknik pembelajaran memiliki kaitan yang erat. Menurut Ngalim Purwanto (2002: 182) reward adalah alat untuk mendidik anak-anak supaya anak dapat merasa senang karena perbuatan atau pekerjaannya mendapat penghargaan. Dengan adanya reward akan menumbuhkan keinginan siswa untuk mengulangi perbuatannya tersebut agar mendapatkan penghargaan.

Jadi, maksud dari teknik reward adalah langkah-langkah yang ditempuh guru bertujuan membentuk kata hati dan kemauan yang lebih baik dan lebih keras pada siswa untuk belajar. Hal yang terpenting bukanlah hasil yang dicapai seorang siswa, tetapi kemauansiswa mencapai hasil $b$.

\section{Fungsi reward}

Menurut Oemar Hamalik (2008: 167) reward atau penghargaan memiliki tiga fungsi penting dalam mengajari anak berperilaku yang disetujui secara sosial. Fungsi yang pertama ialah memiliki nilai pendidikan.
Yang kedua, pemberian reward menjadi motivasi bagi anak untuk mengulangi perilaku yang diterima oleh lingkungan atau masyarakat. Melalui reward, anak justru akan lebih termotivasi untuk mengulangi perilaku yang memang diharapkan oleh masyarakat. Fungsi yang terakhir ialah untuk memperkuat perilaku yang disetujui secara sosial dan tiadanya penghargaan melemahkan keinginan untuk mengulangi perilaku tersebut.

Menurut Bandura (dalam J. W. Santrock, 2007: 516-517) terdapat dua fungsi Reward yaitu 1) sebagai insentif agar mau mengerjakan tugas yang bertujuan mengontrol perilaku siswa, 2) mengandung informasi tentang penguasaan keahlian.

Berdasarkan beberapa pendapat mengenai fungsi reward di atas, maka dapat ditegaskan dalam penelitian ini, reward berfungsi memberikan nilai pendidikan, mengulangi perbuatan yang disetujui lingkungan, memperkuat perbuatan yang disetujui lingkungan, sebagai insentif agar mau mengerjakan tugas yang bertujuan mengontrol perilaku siswa .

\section{Model Penggunaan Teknik Reward}

Menurut Saiful Bahri Djamarah (2005: 122) terdapat beberapa model dalam penggunaan teknik reward, yaitu:

1) Penguatan seluruh kelompok

Penguatan ini diberikan secara terus menerus dalam satu kelompok atau satu kelas. Penguatan ini dapat berbentuk verbal (seperti "kalian hebat, pandai, pinter, bagus, sip), gestural (berupa acungan jempol,anggukan), tanda (seperti penghargaan berupa bintang), dan kegiatan (seperti kegiatan kunjungan karyawisata).

2) Penguatan yang ditunda

Penguatan yang ditunda ini maksudnya adalah penguatan yang diberikan setelah melakukan respon/ tanggapan terhadap rangsangan yang diberikan guru. Penguatan yang dibunakan dapat berupa apa saja yang member dampak positif siswa.

3) Penguatan partial 
Penguatan ini bersifat sebagiansebagian artinya tidak utuh, dan tidak berkesinambungan serta diberikan kepada siswa yang memberikan respon terhadap rangsangan guru. Penguatan partial ini digunakan untuk menghindari penguatan negatif dan pemberian kritik.

4) Penguatan perorangan

\begin{tabular}{llr}
\multicolumn{2}{c}{ Penguatan } & perorangan ini \\
diberikan secara khusus kepada & andi \\
seseorang atas kemampuan dimiliki
\end{tabular}
siswa namun tidak dimiliki siswa yang lain. Penguatan ini dapat dilakukan dengan menyebut nama siswa, menyebut kemampuannya atau penampilannya.

Dari pendapat di atas mengenai model penggunaan reward, pada penelitian ini semua model di atas digunakan sesuai dengan situasi dan kondisi yang tepat.

\section{Karakteristik Siswa SD}

Peserta didik atau siswa merupakan anggota masyarakat yang berusaha mengembangkan potensi diri melalui proses pembelajaran yang tersedia pada jalur, jenjang, dan jenis pendidikan tertentu (Sisdiknas no. 20 tahun 2003). Karakteristik peserta didik merupakan keseluruhan kelakukan dan kemampuan yang ada pada peserta didik sebagai hasil dari pembawaan dan lingkungan sosialnya sehingga menentukan pola aktivitasnya dalam meraih cita-citanya. Guru dalam menentukan tujuan belajar harus disesuaikan dengan kar akteristik siswa tersebut.

Menurut Sardiman A.M (2007: 121) karakteristik peserta didik yang dapat mempengaruhi kegiatan belajar siswa antara lain: 1) latar belakang pengetahuan dan taraf pengetahuan, 2) gaya belajar, 3) usia kronologi, 4) tingkat kematangan, 5) ruang lingkup minat, 6) lingkungan sosial ekonomi, 7) hambatan-hambatan lingkungan dan kebudayaan, 8) intelegensia, 9) keselarasan dan attitude, 10) prestasi belajar, dan 11) motivasi. Usia siswa pada jenjang SD di Indonesia adalah 7-12 tahun yang termasuk dalam masa kanak-kanak akhir. Rita Eka Izzaty (2008: 116-117) menyatakan bahwa masa kanak-kanak akhir dibagi menjadi dua fase, yaitu: a. Masa kelas-kelas rendah Sekolah Dasar yang berlangsung antara usia $6 / 7$ tahun 9/10, biasanya mereka duduk di kelas 1,2 dan 3 Sekolah Dasar.

b. Masa kelas-kelas tinggi Sekolah Dasar, yang berlangsung antara usia 9/10 tahun - 12/13, biasanya mereka duduk di kelas 4, 5, dan 6 Sekolah Dasar. Tiap-tiap fase anak memiliki ciri khas yang berbeda-beda.

Berdasarkan teori di atas, dapat disimpulkan bahwa karakteristik anak-anak masa kelas rendah pada usia Sekolah Dasar memiliki karakteristik suka mendapat pujian, egois tinggi dengan menggangap diri sendiri yang benar dan meremahkan orang lain.

\section{METODE PENELITIAN Jenis Penelitian}

Penelitian ini menggunakan jenis Penelitian Tindakan Kelas (classroom Action Research). Pola pelaksanaan Penelitian Tindakan Kelas ini dilakukan dengan melakukan pola kolaboratif. PTK ini bertujuan untuk meningkatkan hasil belajar pada pembelajaran tematik integratif dengan menggunakan teknik reward.

\section{Desain Penelitian}

Desain penelitian tindakan kelas ini menggunakan model spiral Kemmis dan Taggart yang terdiri dari siklus-siklus. Model spiral ini dikembangkan oleh Stephen Kemmis dan Robin Taggart. Penelitian ini dilaksanakan dalam beberapa siklus dengan setiap siklusnya terdiri dari tahapan-tahapan, yaitu: perencanaan (planning), tindakan (action) dan pengamatan (observation), dan refleksi (reflection) (Suharsimi Arikunto, 2006: 93).

Pada setiap siklus dilakukan dalam beberapa kegiatan pembelajaran. Siklus pertama mendasari penentuan dan pengembangan siklus kedua, dimana siklus kedua merupakan perbaikan dari siklus pertama dan seterusnya untuk meningkatkan kualitas pembelajaran. Pada akhir kegiatan pembelajaran siklus pertama dilakukan evaluasi dan refleksi untuk mengetahui efektivitas pembelajaran dan kemungkinan berbagai kendala yang mungkin d itemukan. Keputusan untuk menghentikan atau melanjutkan siklus merupakan keputusan 
bersama antara guru kelas selaku peneliti dan mitra kolaborasi. Siklus dihentikan jika peneliti /guru kelas sepakat bahwa hasil belajara siwa telaah meningakat dengan ketentuan jka siswa yaang tuntas belajar $\geq 80$ $\%$. Gambar siklusnya adalah sebagai berikut
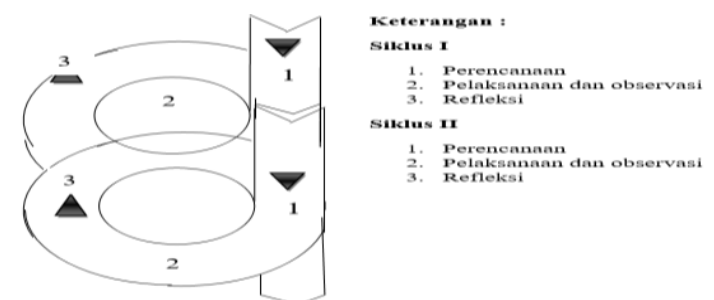

Gambar 1. Model Siklus Kemmis dan Mc Taggart (Suharsimi Arikunto, 2006: 93)

\section{Subjek Penelitian}

Subjek dalam penelitian ini adalah siswa kelas I SDN Sintung Timur Kecamatan Pringgarata Kab. Lombok Tengah yang berjumlah 25 siswa, yang terdiri dari 15 siswa laki-laki dan 10 siswa perempuan.

\section{Setting}

Tempat Penelitian

Penelitian ini dilakukan di kelas I SDN Sintung Timur Kecamatan Pringgarata Kab. Lombok Tengah. Setting penelitian yang digunakan dalam penelitian ini adalah setting di dalam kelas, untuk mengetahui hasil belajar siswa dalam pembelajaran tematik integratif dan pelaksanaan pembelajaran tematik integratif yang dilakukan guru melalui metode drawing

\section{Teknik Pengumpulan Data}

Teknik pengumpulan data merupakan langkah yang paling utama dalam penelitian, karena tujuan utama dari penelitian adalah memperoleh data (Sugiyono, 2008: 308). Teknik pengumpulan data yang tepat akan membuat data yang diperoleh valid dan dapat dipertanggung jawabkan secara ilmiah. Adapun teknik pengumpulan data yang digunakan dalam penelitian ini adalah: adalah menggunakan tes..

\section{Analisis Data Penelitian}

Tujuan analisis data dalam penelitian tindakan kelas ini adalah untuk memperoleh bukti kepastian apakah terjadi, peningkatan Hasil belajar dalam pembelajaran Sub tema Tubuhku sebagaimana yang diharapkan. Analisis data yang digunakan oleh peneliti adalah teknik kuantitatif, data kuantitatif diperoleh dari hasil tes. Secara rinci, analisis dalam penelitian ini adalah sebagai berikut:

\section{Analisis Data kuantitatif}

Hasil tes dideskripsikan dalam bentuk data konkret, berdasarkan skor minimal, dan skor maksimal, sehingga diperoleh skor rata-rata. Selanjutnya diambil simpulan berdasarkan hasil analisis data yang diperoleh. Hasil belajar memiliki Kriteria Ketuntasan Minimal (KKM) yang harus dicapai siswa. Untuk sub tema Tubuhku kelas I semster 1 SDN Sintung Timur ditetapkan KKM 70. Data yang akan dianalisis secara deskriptif kuantitatif berupa hasil evaluasi siswa yang dinyatakan dengan skor dari hasil tes evaluasi dengan menggunakan statistik deskriptif yaitu mencari nilai rata-rata (mean) dan persentase keberhasilan belajar. Rumus mean atau rerata nilai (Suharsimi Arikunto, 2007: 284-285):

$$
\mathrm{R}=\frac{\sum \mathrm{S}}{\sum \mathrm{N}} \times 100
$$

Keterangan :

$\mathrm{R}$ =rata-rata kelas (mean)

$\sum \mathrm{S}=$ jumlah skor (nilai siswa)

$\sum \mathrm{N}=$ banyaknya siswa

Sedangkan rumus untuk menghitung persentase siswa yang lulus adalah sebagai berikut :

$$
P=\frac{F}{N} \times 100 \%
$$

Keterangan :

$\mathrm{P}=$ Angka persentase

$\mathrm{F}=$ Frekuensi yang sedang dicari

persentasinya

$\mathrm{N}=$ Jumlah siswa/ sampel

\section{HASIL PENELITIAN DAN PEMBAHASAN \\ Deskripsi Data}

Sesuai dengan tujuan penelitian yang telah ditetapkan sebelumnya bahwa penelitian ini bertujuan untuk meningkatkan hasil belajar siswa pada subtema Tubuhku meelalui pendekatan tematik denagan metode Biodrawing

\section{Analisis Data}

Siklus Pertama 
Pelaksanaan tindakan kelas pada siklus I dilaksanakan pada semester I tanggal 31 juli 2018 selama kurang lebih 3 jam pelajaran (3 x 35). Berdasarkan Pengolahan hasil beljar siswa dapat dijelaskan hasil belajar siswa kelas I pada siklus I, nilai rata rata sebesar 65 dengan persentase ketuntasan $60 \%$ atau sebanyak 15 orang sudah tuntas belajar dan persentas siswa yang tidak tunts sebanyak $40 \%$ atau 10 orang siswa belum tuntas belajar ini dikarenakan siswa terlalu banyak main - main dan guru kurang kontrol di dalam kelas,karena ketuntasan klasikal belum tercapai maka penelitian ini dilanjutkan kembali kesiklus berikutnya.

\section{Refleksi}

Setelah dilakukan perencanaan, tindakan dan pengamatan, peneliti bersama kolaborator mengadakan refleksi dan tindakan-tindakan yang telah dilakukan, yaitu pembelajaran melalui penerapan polapelatihan berjenjang.

\section{Siklus kedua}

Siklus II dilaksanakan pada hari Senin tanggal 14 Agustus 2018 di kelas I dengan jumlah siwa sebanyak 25 siswa. Hasil belajar siswa setelah diadakan perbaikan pada proses belajar mengajar adalah; nilai rata rata sebesar 84,40 dengan persentase ketuntasan $92 \%$ atau sebanyak 23 orang sudah tuntas belajar dan persentase siswa yang tidak tuntas sebanyak $8 \%$ atau 2 orang siswa belum tuntas belajar, maka dengan demikian penelitian ini di hentikan sampai pada siklus II, karena ketuntasan klasikal sudah tercapai yaitu $\geq 80$.

\section{Pembahasan Hasil Penelitian}

Berdasarkan data hasil belajar siswa yang tertera pada tabel data siklus I dan siklus II dapat dibandingkan hasil belajar siswa . Hasil belajar siswa kelas I pada siklus I ,memperoleh nilai rata - rata sebesar 65 dengan persentase ketuntasan $60 \%$ atau sebanyak 15 orang sudah tuntas belajar dan persentase siswa yang tidak tuntas sebanyak $40 \%$ atau 10 orang siswa belum tuntas belajar ini dikarenakan siswa terlalu banyak main - main dan guru kurang kontor di dalam kelas,karena ketuntasan klasikal belum tercapai maka penelitian ini dilanjutkan kembali kesiklus berikutnya .
Hasil belajar siswa kelas I pada siklus II ,memperoleh nilai rata - rata sebesar 84,40 dengan persentase ketuntasan $92 \%$ atau sebanyak 23 orang sudah tuntas belajar dan persentase siswa yang tidak tuntas sebanyak $8 \%$ atau 2 orang siswa belum tuntas belajar ini maka dengan demikian penelitian ini di hentikan sampai pada siklus II, dan ketuntasan klasikal sudah tercapai yaitu angka $\geq 80$.Dari kedua data tersebut dikatakan peningkatan cukup signifikan hasil belajar siswa dari sikus I ke siklus II dimana pada siklus I diperoleh nilai rata - rata sebesar 65 meningkat pada siklus II menjadi 84,46 terjadi peningkatan sebesar 19,46 poin ,kemudian persentase ketuntasan dari siklus I sebesar $60 \%$ meningkat pada siklus II menjadi $92 \%$ meningkat sebesar 32 poin ,maka dengan demikian dapat ditarik kesimpulan bahwa Pendekatan Tematik dengan Menggunakan Media Biodrawing dapat Meningkatkan Hasil Belajar subtema Tubuhku pada siswa Kelas I Semester I SDN Sintung Timur Tahun Pelajaran 2018/2019

\section{KESIMPULAN DAN SARAN}

Dikatakan peningkatan cukup signifikan hasil belajar siswa dari sikus I ke siklus II dimana pada siklus I diperoleh nilai rata - rata sebesar 65 meningkat pada siklus II menjadi 84,46 terjadi peningkatan sebesar 19,46 poin ,kemudian persentase ketuntasan dari siklus I sebesar $60 \%$ meningkat pada siklus II menjadi $92 \%$ meningkat sebesar 32 poin maka dengan demikian dapat ditarik kesimpulan bahwa Pendekatan Tematik dengan Menggunakan Media Biodrawing dapat Meningkatkan Hasil Belajar subtema Tubuhku pada siswa Kelas I Semester I SDN Sintung Timur Tahun Pelajaran 2018/2019

\section{DAFTAR PUSTAKA}

Ainurrahman. (2010). Belajar dan Pembelajaran. Bandung: Alfabeta.

Dimyanti dan Mujiono. (2013). Belajar dan Pembelajaran . Jakarta: Rineka Cipta.

Dwi Siswoyo. (2007). Ilmu Pendidikan. Yogyakarta: UNY Press.

Ellis Ormrod, Jeanne. (2008). Psikologi Pendidikan (Alih bahasa: Dra. Wahyu Indianti, M. Si., dkk). Jakarta: Erlangga. 
Hamzah B. Uno. (2013). Teori Motivasi dan Pengukurannya. Gorontalo: Bumi Aksara. (2003).

H. A. R Tilaar. (2002). Pendidikan, Kebudayaan dan Masyarakat Madani Indonesia. Bandung: Rosdakarya.

John M. Echols. (2003). Kamus Bahasa Inggris-Indonesia. Jakarta: PT. Gramedia Pustaka Indonesia

Kemendikbud. (2003). Undang-Undang RI Nomor 20 Tahun 2003 tentang Sistem Pendidikan Nasional. Bandung: Citra Umbar a.

Peraturan Menteri Pendidikan dan Kebudayaan Republik Indonesia tentang No. 67 tahun 2013 tentang Kerangka Dasar dan Struktur Kurikulum SD/ MI . Jakarta: Kemendikbud

Muhibbin Syah. (2008). Psikologi Pendidikan. Jakarta: Rosdakarya.

Nana Syaodih Sukadinata. (2004). Landasan Psikologi Proses Pendidikan. Bandung: Remaja Rosdakar ya.

Ngalim Purwanto. (2002). Ilmu Pendidikan Teori dan Praktis. Bandung: Rosdakarya.

Oemar Hamalik. (2008). Proses Belajar Mengajar. Jakarta: Bumi Aksara.

Rian Putri Hapsari. (2013). Studi Tentang Pelaksanaan Pemberian Reward Dalam Meningkatkan Motivasi Belajar Kelompok A di TK Islam Al Azhar 35 Surabaya.

Saiful Bahri Djamarah. (2005). Guru dan Anak Didik. Bandung: Alfabeta.

Santrock. J. W. (2010). Psikologi Pendidikan. Jakarta: Bumi Aksara

Sardiman A. M. (2012). Interaksi dan Motivasi Belajar Mengajar edisi revisi . Jakarta:

Rajawali. .(2007). Interaksi dan Motivasi Belajar Mengajar. Jakarta: Rajawali.

Sudjana. (2001). Metode dan Teknik Pembelajaran Partisipatif. Bandung: Falah Production.

Sugihartono, dkk. (2007). Psikologi Pendidikan. Yogyakarta: UNY Press.

Sugiyono. (2009). Metode Penelitian Pendidikan. Bandung: Alfabeta.
Suharsimi Arikunto. (2006). Prosedur Penelitian Suatu Pendekatan Praktik. Jakarta: Rineka Cipta.

Suharsimi Arikunto, Suhardjono \& Supardi. (2005). Penelitian Tindakan Kelas. Jakarta: Rineka Cipta.

Sumardi Suryabrata. (2006). Psikologi Pendidikan. Jakarta: Raja Grafindo Persada.

Trianto. (2011). Desain Pengembangan Pembelajaran Tematik bagi Anak Usia Dini TK/ RA dan Anak Usia Kelas Awal SD/ MI. Jakarta: Kencana 